FACTA UNIVERSITATIS

Series: Law and Politics Vol. 16, $\mathrm{N}^{\mathrm{o}} 1,2018$, pp. 57-67

https://doi.org/10.22190/FULP1801057B

Review Paper

\title{
CORRUPTION AS AN OBSTACLE TO EUROPEAN INTEGRATIONS
}

\author{
UDC 343.352(4-672EU)
}

\author{
Rade Bogojević ${ }^{1}$, Tatjana Skakavac ${ }^{2}$ \\ ${ }^{1}$ Centre for Basic Police Training, Sremska Kamenica, \\ Ministry of Interior, Republic of Serbia \\ ${ }^{2}$ Faculty of Legal and Business Studies "dr Lazar Vrkatić", Novi Sad, \\ Union University, Belgrade, Republic of Serbia
}

\begin{abstract}
Corruption is not a phenomenon of recent times. It derives from the Latin word "corruptus", meaning deterioration, blackmail, depravity, bribery, etc. The ancient Greeks and Romans faced this phenomenon and enacted rules aimed at its prevention and suppression. The practice of bribery is as old as the state itself. In the 18th century England, for example, the notion of corruption was associated not only with corrupt government but also with giving bribes. Despite numerous efforts of the international community to put an end to this problem, the fact is that many countries have not ratified the proposed documents of this type yet. In terms of criminal law, corruption-related offences in Serbia today include primarily crimes against official duties, crimes against the economy, and crimes against freedom and civil rights. In this paper, the authors examine some issues related to corruption in light of its harmful effects on the European Integration process.
\end{abstract}

Key words: corruption, corruption-related offences, prevention,suppression, abuse, economy.

\section{INTRODUCTORY REMARKS}

There is a common belief that there is no society without corruption and that all socioeconomics systems, in both developed and undeveloped countries, are prone to corruptive practices. Due to the high level of threat to society and danger for the operation of the state and economic institution, in the international community corruption has given the same priority as terrorism and organized crime (Konstatinović-Vilić, Nikolić, Kostić, 2009: 179).

Received July $20^{\text {th }}, 2017$ / Accepted August $7^{\text {th }}, 2018$

Corresponding author: Rade Bogojević, LL.D., Police Counselor, Deputy Director at Centre for Basic Police Training, Sremska Kamenica, Ministry of Interior, Republic of Serbia

E-mail: tatjana.skakavac@gmail.com 
Corruption mainly occurs in times of crisis and disintegration of a country, when public services become empoverished and depleted, and when the political and economic systems start decomposing and transforming. Generally speaking, it can be said that corruption is one of the most dangerous forms of economic crime. In many societies, this socially unacceptable phenomenon seems to have become a customary form of behaviour. In Serbia, as well as in many other countries, the term "corruption" started being used rather recently. It was mainly related to bribery, which is defined as a gift in money or some other valuable item aimed at luring a person to fulfil the bribe-giver's wish, most frequently in illegal ways.

The contemporary theory emphasizes that political power and influence cannot be sold and bought, as well as that the official position cannot be subject to trade. However, we bear witness that there is a significant difference between these generally accepted principles and practice. For this reason, the abuse of political and official position is sanctioned in criminal law. In the most general sense, corruption represents the abuse of power that is vested in a specific office, post or job position in the socal or economic hierarchy for illegal acqusition of wealth or status (Bošković, 2007, str. 353).

When Serbia is concerned, corruption is present in all segments of social life. Hence, it is listed among countries with high level of corruption. We certainly cannot ignore the fact that the political events and socieo-economic circumstances in the past two decades have significantly contributed to the development of such practices. A more coordinated approach to fighting corruption is certainly inevitable, which necessarily calls for more substantial engagement of all competent institutions at the national and international level alike.

\section{ISSUES IN DEFINING THE CONCEPT OF CORRUPTION}

There are several problems in defining the concept of corruption. The most prominent one is the fact that there is no common and internationally accepted definition of corruption, which has a negative impact on both criminology and criminalistics because it significantly affects the process of identifying the causes of corruption and applying the relevant methods for its supression. Another problem is that many criminal activities in the area of corruption-related crimes cannot be classified under the existing criminal offences, whereas many corruptive practices in the field of public affairs are not sanctioned by criminal law. When corruption in the private sector is concerned, another problem is the impunity for committing these offences. Namely, in some countries, the legislative framework does not envisage the legal enties and persons employed in the private sector as possible perpetrators of corruption-related criminal offences. It should be noted that corruption is present in other economic and non-economic areas, such as: industry and civil engineering, banks and other financial organisations, insurance institutions, employment sector, media, sport, healthcare, education, art, show business, etc. Consequently, there are different definitions of corruption but their common feature is that they all entail the abuse of public service for the purpose of obtaining some benefit for oneself or another.

A further problem in defining the concept of corruption is that it can be viewed from different aspects: psychological, sociological, criminological, or legal. It is considered that corruption can be defined as 'the illness of leaders', i.e. as a situation in which the person authorized to make decisions and take actions in the public interest modifies the decision and actions guided by private interests. Another inevitable issue in defining the 
notion of corruption pertains to its different forms. In theory, corruption is classified as follows: a) petty, minor, and grand corruption; b) sporadic (endemic) or systemic; and c) simple or complex (Mrvić-Petrović, 2001: 21-22). In addition, there are the following forms of corruption: low-level or street-level corruption; contractual corruption or corruption in public administration; political corruption; economic corruption; court corruption (Petrović, Meško, 2004: 186).

In line with the UN Convention against Corruption (2003) and given the diversity of its forms, most European criminal legislations classify corruption into two basic forms: active and passive corruption. Active corruption entails the criminal act of offering, promising or giving a gift, benefit or priviledged exercise of a right. Passive corruption exists when someone in official or private position accepts an offer, gift, benefit or a promise of gift or benefit, and thus commits a criminal offence.

Both before and after the ratification of the UN Convention against Corruption (2003), the aspiration to suppress corruption in Serbia imposed the need to ratify many other international documents, such as: the UN Convention against Transnational Organized Crime (2000), the Council of Europe Criminal Convention on Corruption and Civil Law Convention on Corruption (1999), the Council of Europe Convention on Laundering, Search, Seizure and Confiscation of the Proceeds from Crime (1990), the Council of Europe Convention on Laundering, Search, Seizure and Confiscation of the Proceeds from Crime and on the Financing of Terrorism (2005).

\section{NeGAtive EFFECT OF CORRUPTION ON THE DEVELOPMENT OF MODERN SOCIETY}

For a long time, fear of harsh punishment was the only form of deterrence from committing corruption-related criminal offences. Offenders of such offences were executed as murderers and enemies of the state. However, such harsh punishments did not produce adequate results. It is probably due to the fact that the emergence and development of corruption was largely influenced by the holders of political power holders, while legislative bodies had little impact. Even today, corruption is the most clandestine type of criminal activity; therefore, 'the dark figure' of committed criminal offences of this type is rather high. The high level of clandestinity comes from the fact that the one who gives and the one who takes bribe are equally interested not to be disclosed. One thing is sure: corruption is difficult to prove by currently available methods and legal instuments, which particularly refers to corrupt activities involving public officials. The control mechanisms are largely inadequate and inapplicable, and the system of competencies for combating corruption is undefined.

Suppressing corruption only through criminal laws is considered to be insufficient way of combating this social phenomenon. Excessive repression is considered inadequate because it creates a perception that combating corruption is not the problem of the entire society but an issue which has to be handled exclusively by the police, prosecution and courts. The efforts made in this domain result in defining different programmes in order to eradicate corruption from public life, especially by eliminating the abuse of public functions, which have been the subject matter of some major corruption scandals. In combating corruption, some countries have gone so far as to include relevant provisions in their constitutions. Corruption during the national elections for people's representatives in state intitutions is particularly dangerous because such practices directly affect the outcome of election results. Elections won in that way have immense negative consequences on the operation of the legislative body and executive authorities as the most important decision-makers. 
The influence of corruption on the economic development of a society mainly depends on the nature and prominence of this phenomenon in each state. In modern economies, the correlation between the legislative, executive and judicial authorities, and their correlation with political structures, is very important because it establishes mutual relations between those who make decisions and those who run the country, ensures feedback and provides guidelines for further action. There is no dispute that infiltration of corruption into the key public administration offices is highly detrimental. The constant bias, favorism and privileges given to some at the expense of others impede the process of developing conditions for creating a strong economy (Stajić, 2008, str. 163).

Decision-making centres in poor Asian and African countries, and Eastern European countries in transition, are most susceptible to corruption. According to the findings of Transparency International (TI), international corporations and businessmen from the most developed countries (such as: Sweeden, Australia, Canada, Austria, Switzerland, Netherlands, Great Britain, Belgium, Germany and USA) are also enlisted as those who offer bribe (Stajić, 2008:168)

\section{NEGATIVE EFFECT OF CORRUPTION ON EUROPEAN INTEGRATIONS}

When it comes to European integrations, the question of corruption takes the prominent first place. Corruptive practices not only prevent but also considerably slow down political and economical reforms in all countries, especially in countries in transition. The Report of the European Comission, ${ }^{1}$ submitted to the countries of Central and Eastern Europe, candidates for the EU accession, states that there has been very little progress in terms of corruption. This conclusion of the European Comission was given on the basis of analyses conducted by the World Bank, OECD and other international organizations that were active on the question of corruption prevention and suppression. The analyses of the countries in transition led to irrefutable facts that 'tycoons' exert significant influence on politicians, judicial and other state bodies to adopt legal solutions which would facilitate to conceal their corrupt activities. For example, in transition countries, there is a common practice of "rigging" the sale of companies during the privatisation process. The institutional govenmental control proved to be inadequate in most countries. The EC Report also showed that most MPs have a lack of awareness about their competences and accountability, as well as insufficient knowledge about the problems that government has to deal with (EC Report, 2016).

Due to the detrimental effects of corruption for the society, the police and prosecution authorities worldwide establish special units and bodies aimed at combating corruption and exchange information on this matter. Moreover, Transparency International was established as a special non-governmental organization for combating corruption, which is present in more than eighty coutries throughout the world. In 1998, the Council of Europe established the anti-corruption monitoring body - the Group of States against Corruption (GRECO).

When it comes to Serbia, corruption is not only present but also widespread in all spheres of social life. Serbia falls into the group of countries with high corruption rate. The political events and socio-economic circumstances in the past two decades created

\footnotetext{
1 The European Comission Report: COM (2016) 715 final; https://ec.europa.eu/neighbourhood-enlargement/sites/ near/files/pdf/key_documents/2016/20161109_report_serbia.pdf
} 
convenient environment for corruption. Serbia started taking some steps in counteracting corruption only in 2002, when the Government established the Anti-Corruption Council. After being (re)admitted into the Council of Europe in 2003, Serbia approached the issue of combating corruption more seriously, particularly in view of Serbia's pursuit to become an EU member state. Thus, in 2005, the Serbian National Assembly adopted the National Strategy for fighting against corruption, and the Government of Serbia adopted the Action Plan for its implementation. Finally, the legislative act on establishing an independent anticorruption body - The Anti-Corruption Agency - was adopted, and entered into force on $1^{\text {st }}$ January 2010. The establishment of the Anti-corruption Council and the Anti-Corruption Agency were inevitably followed by difficulties and frequent disagreements with the governing authorities.

Therefore, corruption is an inevitable phenomenon during the process of transition, and it considerably undermines democratic and free market institutions of a society. Accordingly, during transition, a close attention must be paid to combating corruption, which should not be accepted as a matter of habit. Fight against corruption can only be successful through joint efforts of governing authorities, civil society organizations, and private economic entities. Finally, if we want to join the EU, we have to change the bad habits and eradicate corruption.

\section{DifFICULTIES IN PREVENTING AND SUPPRESSING CORRUPTION}

The perpetrators of this type of criminal offences skillfully avoid criminal prosecution, most often because of their 'political status' which enables them to do so. Corruption is indeed most prominent in the public sector, i.e. in state and public institutions, but it is also present in the private sector, particularly in manufacture, trade and services.

Corruption is one of the crudest types of exploitation of subordinate layers of society; concurrently, it is the most perfidious method of capital accumulation of the stronger economic entity at the expense of the weaker one. Corruption is mostly encountered in the context of management structures and control procedures involving property. In most cases, the perpetrators of corruption-related criminal offences try not to have direct contact with property; thus, property-related irregularities and corruptive practices are commonly committed by the abuse of official positions, such as managerial, operational and control functions. The gravity and scope of these abuses are influenced by the economic position of business entity, the conditions on the market, the level of development of economic relations, the organization and operative technology, the level of development of protective mechanism in the business entity, state or other public institution.

Corruption is frequently connected with organized crime and may, to some extent, protect persons from the criminal environment. Public and civil servants, who are supposed to suppress organized crime, are often corrupt themselves. Organized crime resorts to corruptive practices in order to establish and maintain criminal contacts with influential individuals in political structures, state authorities and other areas of public life. When a person from the criminal environment makes a 'deal' with public officers and civil servants, they become regularly frequented 'patients'; at the same time, the criminal organization becames a regular 'patient' of the corrupt servant. Problems ensue when one party tries to walk away from the deal. Using corruption and mass media, criminals from the organized crime milieu present 
themselves to the general public audiences as businessmen and honest citizens, people of trust, successful businessmen, etc.

Political corruption makes one of the most dangerous types of economic crime which organized crimes relies on. The largest threat exists if judicial and police employees are inclined to bribery and abuse of official positions. In that case, the whole legal system of a state is endangered.

Fight against corruption must predominantly include preventive measures, which implise removing the causes that lead to corruption. However, condidering the current level of corruption, repressive measures must not be excluded. Therefore, it is highly important to suppress corruption in the public authorities working on detection, prosecution and adjudication of corruption-related activities, primarily the police and judicial authorities.

In order to prevent corruption, public servants working on this matter have to be fully aware of the professional ethics in performing public services, the efficient supervision and control mechanisms, daily monitoring by the general public, the fact that all final judicial decisions on corruption-related criminal offences will be published in mass media, etc. In view of suppressing corruption, closer cooperation should be established with AntiCorruption Network (ACN) for Transition Economies, which mainly specializes in assisting post-communist countries to improve the performances of their anti-corruption programmes.

\section{CORRUPTION-RELATEd OFFENCES IN SERBIAN LEGISLATION}

The Criminal Code of the Republic of Serbia (CC) ${ }^{2}$ includes a number of corruptionrelated offences which are categorized in different groups. We can single out some criminal offence against freedoms and rights of man and citizen, criminal offences against economic interests, and criminal offences against official duty.

\section{Criminal Offences against Freedoms and Rights of Man and Citizen (Chapter 14)}

1. Violation of Equality (Article $128 \mathrm{CC}$ ): This criminal offence is related to the constitutional principle of citizen equality, and it has the basic and a more serious form. The basic form of this offence is committed by anyone who "denies or restricts rights of a man and citizen guaranteed by the Constitution, laws or other legislation or general acts or ratified international treaties, on grounds of nationality or ethnicity, race or religion or due to absence of such affiliation or difference in political or other conviction, sex, language, education, social status, social origin, property, or other personal charactheristics, or pursuant to such difference grants another privileges or benefits." A more serious form of offence exists when it is committed by an official in discharge of official work.

\footnotetext{
${ }^{2}$ Krivični Zakonik (The Criminal Code of RS), "Sl.Glasnik R.Srbije”, br.85/2005, 88/2005- ispr., 107/2005-ispr. i 72/2009, 111/2009, 121/2012, 104/2013, 108/2014), Beograd.
} 


\section{Offences against Economic Interests (Chapter 22)}

1. Accepting Bribe in Performing Economic Activities (Article $230 \mathrm{CC}$ ): This criminal offence has two basic forms. The perpetrator of the first basic form is a person who, while performing economic activities for oneself or for other, directly or indirectly, solicits or accepts a gift or other benefit, or receives a promise of a gift or other benefit to conclude a contract or make a business arrangement or provide service or to refrain from official actions that he is oblidged to perform, or violates other official acts in performing economic activities in order to harm or give benefit to a business entity or other legal entity that he works for/in or to another. The second basic form of offence occurs when the perpetrator upon concluding the contract or achieving a business deal or upon provided service or not performing an official act, solicits or accepts a gift or other benefit, or promise of a gift or other benefit for oneself or another. The received gift or material gain shall be seized.

2. Bribery in Performing Economic Activities (Article $231 \mathrm{CC}$ ): This criminal offence consists of offering a gift or promising a gift or some other benefit to an official while performing his economic activities, in order to conclude a contract or achieve business arrangement or provide a service or not to perform an official act, or violates other duties while performing economic activities in order to harm or give benefit to a subject of economic activities he works for/in or in order to harm or give benefit to natural person or other legal entity or who mediates in such giving gifts or other benefits. With this criminal offence, Code states that if perpetrator reports the offence before he has found out it has been detected, he can be released from punishment. The received gift or material gain shall be seized.

3. Causing False Bankruptcy (Article 232a CC): This criminal offence has the basic and more serious form. The basic form of this criminal offence has three forms. It is committed by any person in a business entity who has the capacity of a legal person who, with intention to evade paying liabilities incurred by the business entity, causes bankruptcy of the business entity by fictitious or actual decrease of its assets by: 1) concealing, fictitiously selling, selling under the market price or relinquishing without compensation all or part of the assets of the business entity; 2) concluding fictitious contracts on debt or recognising non-existent claims; 3) concealing, destroying or altering business books that the business entity is obliged to keep in accordance with the law, thus making it impossible to discern therefrom the business results or state of assets or liabilities, or making false documents or otherwise falsely presenting the state of affairs on the basis of which bankruptcy may be instituted. A more serious form of offence exists when there are serious consequences for the creditor.

4. Damaging Creditors (Article $233 \mathrm{CC}$ ): This criminal offence has the basic and two more serious forms. The basic form of offence exists when a person in the business entity having the capacity of a legal person, knowing that the entity is insolvent or incapable of paying a debt, pays the debt or otherwise deliberately puts the creditor in a more favourable position and thereby significantly damages another creditor. The first more serious form of offence entails the perpetrator's intention to deceive or damage the creditor by recognising false claims, making false contracts or otherwise fraudulently damaging the creditor. The second more serious form occurs when the creditor experiences extensive damage or when the compulsory settlement or bankruptcy procedure is consequently instituted against the injured party. 
5. Disclosing a Business Secret (Article 240 CC): This criminal offence has the basic and a more serious form. The basic form exists when the perpetrator communicates to another without authorisation, hands over or in any other way makes available the information representing a business secret, or obtains such data with intention to hand them over to an unauthorised person. A more serious form implies that offence is committed for benefit (gain) or in respect of particularly confidential information. The priviledged form of offence exists when it is committed as a result of negligence, in which case the legislator envisages a milder punishment. Two conditions have to be met in order to declare some data a business secret. The first (formal) condition is that these pieces of information are declared a business secret by law, other regulation or a decision of competent authority issued in accordance with the law. The second (substantive) condition is that the disclosure of such data has caused or could cause harmful consequences for the economic/business entity.

\section{Criminal Offences against Official Duty (Chapter 33)}

1. Abuse of Office (Article 359 CC): This criminal offence has the basic form and two more serious forms. The basic form exists when an official, by abuse of office or authority, by exceeding the limits of his official authority or by failing to perform the official duty, acquires any benefit for himself or another, or causes damage or seriously violates the rights of another. A more serious form of offence occurs when the aquired material gain stemming from the commission of this act exceeds 450,000 RSD (four hundred and fifty thousand dinars). The second more serious form exists if the value of acquired material gain exceeds 1,500,000 RSD (one million five hundred thousand dinars).

2. Violation of the Law by a Judge, Public Prosecutor or his Deputy (Article 360 CC): This criminal offence exists when a judge or a lay judge, a public prosecutor or his deputy involved in court proceedings issues an unlawful act or otherwise violates the law, with intent to acquire some benefit or to cause damage to another. The first more serious form of offence exists if the value of the acquired material gain exceeds 450,000 RSD (four hundred and fifty thousand dinars). The second more serious form of offence exists if the acquired gain exceeds 1,500,000 RSD (one million five hundred thousand dinars).

3. Trading in Influence (Article 366 CC): This criminal offence has four forms. The first incriminated form entails the act of soliciting or accepting a gift or any other benefit for oneself or another, either directly or through a third party, and using the official or social position or real or percieved influence in order to intercede for performance or nonperformance of an official act. The second form of this offence is envisaged in case the perpetrator directly or through a third party promises, offers or gives a gift or any other benefit and uses the official or social position or real or perceived influence to intercede for performance or non-performance of an official act. The third form of this offence refers to the perpetrator who, by abusing his official or social position or influence, intercedes for performance of an official act that should not be performed or for nonperformance of an official act that must be performed. The fourth form of the offence is commiteed by a person who promises, offers or gives a gift or any other benefit to another to intercede by using his official or social position or influence for performance of an official act that should not be performed or for non-performance of an official act that must be performed. In all cases, the prescribed sanctions are the seizure of gifts or 
any other property gain as well as the security measure of compulsory seizure of property items. This Article also includes a provision on the liability of a foreign official who commits this criminal offence.

4. Accepting Bribes (Article $367 \mathrm{CC}$ ): This criminal offence has three basic and one more serious form. The first basic form refers to an official who directly or indirectly solicits or accepts a gift or some other benefit, or accepts a promise of a gift or some other gain for oneself or another, in order to perform an official act that shall not be performed or not to perform an official act that must be performed within the framework of the official authority. The second basic form exists if an official directly or indirectly solicits or accepts a gift or some other gain, or receives a promise or some other gain, to perform an official act that must be performed or not to perform an official act that shall not be performed within the framework of the official authority. The third form of this offence is committed when an official, after performing or non-performing the previously described official act, solicits or receives a gift or some other benefit. A more serious form of this criminal offence refers to an official who has committed the first two forms of the criminal offence in the course of detecting a criminal offence, initiating or conducting criminal proceedings, imposing or enforcing criminal sanctions. In all cases, the prescribed sanctions are the seizure of gifts or any other property gain as well as the security measure of compulsory seizure of property items. This Article also includes a provision on the liability of a foreign official who commits this criminal offence.

5. Giving bribes (Article $368 \mathrm{CC}$ ): This criminal offence has two basic forms. The first form is committed by a person who makes, offers or promises a gift or any other benefit to an official or another person to perform an official act within his official competence that shall not be performed or not to perform an official act that must be performed, or a person who acts as an intermediary in bribing an official. The second form of this offence pertains to the perpetrator who offers or promises a gift or some other benefit to an official or another person in order to perform an official act that must be performed or not to perform an official act that shall not be performed within his official competence, or the person who acts as an intermediary in bribing an official. Yet, the perpetrator of this offence may be exempt from punishment if he reports the offence before finging out that it has been detected.

6. Disclosure of Official Secrets (Article 369 CC): This criminal offence has the basic, a more serious and a privileged form. The basic form of offence is committed by an official who without authorization communicates, delivers or makes the information representing an official secret available otherwise, or obtains such data with intent to give them to an unathorised person. The more difficult form of offence exists when it is committed for gain, or in case of particularly confidential information, or when the data are inteded for publishing or use abroad. The privileged form exists when the offence is committed due to negligence. These provisions also apply to former officials who disclose an official secret after the termination of their public or official duty.

\section{CONCLUSION}

A certain level of corruption is an inevitable part of every society. It cannot be entirely eliminated and, thus far, it has not been possible to create a system which would be fully immune to corruption. However, it is possible to take action to counteract, 
suppress and reduce the scope of this negative social phenomenon. It can be achieved by providing relevant education and training of public and civil servants, and by reinforcing preventive measures. It would preclude the detrimental effects of corruption which substantially undermines the operation of democratic and economic institutions.

In societies with low corruption rate, the priority is to establish new values, i.e. to increase the well-being of society, whereas in societies with high corruption rate the priority is to redistribute the existing values.

In Serbia, the authorities vested in the police and the Anti-corruption Agency are certainly insuficient for combating corruption, particularly given the fact that their members are not sufficiently trained for this area of work. Progressive efforts should be taken to establish multidisciplinary teams, including police officers, Agency employees and a large number of experts whose coordinated activities would be aimed at counteracting the growing problem of corruption in society.

The fact that corruption-related criminal offences are committed in a specific manner cause difficultiess in their detection and further aggravates the process of proving the commission of such offfences. For this reason, contemporary criminalistic methods based on the latest scientific and technical achievements must be used in detecting, fact-finding and proving corruption-related criminal offences.

In the Republic of Serbia, the latest amendments to the Criminal Code (2016) have resulted in expanding the number of envisaged corruption-related criminal offences. Within the framework of criminal offences against economic interests, the legislator introduced two new criminal offences: the crimal offence of accepting bribe in perfoming economic activities, and the criminal offence of giving bribe in performing economic activities. It will certainly contribute to a more efficient fight against corruption.

\section{REFERENCES}

Bošković M., (2007), Kriminologija (Criminology), Pravni fakultet, Novi Sad.

Bošković M., (1999), Kriminološki leksikon (Criminological Lexicon), Matica srpska, Novoi Sad.

Bošković M., (2000), Aktuelni problemi suzbijanja korupcije (Current problems in counteracting corruption), Policijska akademija, Beograd.

Bošković M., (2003), Transnacionalni organizovani kriminalitet (Transnational Organized Crime), PA, Beograd.

Bošković M., Banović, B., (2001). Kriminalistička metodika (Methods in Criminalistics), VŠUP, Zemun.

Jelačić M., Stajić, LJ., (1996), Korupcija kao savremeni društveni problem (Corruption as a contemporary social problem), Srpsko udruženje za krivično pravo, Beograd.

Konstatinović-Vilić S., Nikolić-Ristanović V., Kostić M., (2009), Kriminologija (Criminology), Pelikan print, Niš.

Mrvić-Petrović N., (2001), Korupcija i strategija njenog suzbijanja (Corruption and strategy for counteracting corruption), Časopis Temida, br.4, Beograd.

Teofilović N., Jelačić M., (2006). Sprečavanje, otkrivanje i dokazivanje krivičnih dela korupcije i pranja novca (Prevention, Detection and Proving corruption-related criminal acts and money laundering), Policijska akademija, Beograd.

Stajić LJ., (2008). Osnovi sistema bezbednosti sa osnovama istraživanja bezbednosnih pojava (Security System and fundamental research on security-related phenomena), Pravni fakultet, Novi Sad.

Petrović A., (1981). Kriminalistička metodika (Methods in Criminalistics), VŠUP Zemun.

Petrović B., Meško G., (2004), Kriminologija (Criminology), Pravni fakultet Univerziteta u Sarajevu.

Krivični Zakonik, (Criminal Code of the Republic of Serbia), "Sl.Glasnik R.Srbije”, br.85/2005, 88/2005- ispr., 107/2005-ispr. i 72/2009, 111/2009, 121/2012, 104/2013, 108/2014), Beograd.

Zakon o izmenama i dopunama Krivičnog Zakonika od 23.11.2016. godine (Act on amending and supplementing the Criminal Code of RS), "Sl.Glasnik R.Srbije”, br.94/16, Beograd.

European Commission Report: Commission Staff Working Document: Serbia 2016 Report, Accompanying the document Communication from the Commission to the European Parliament, the Council, the European 
Economic and Social Committee and the Committee of the Regions 2016 Communication on EU Enlargement Policy $\{\mathrm{COM}(2016) 715$ final $\} ;$ https://ec.europa.eu/neighbourhood-enlargement/sites/near/files/pdf/key_ documents/2016/20161109_report_serbia.pdf

\section{KORUPCIJA KAO PREPREKA EVROPSKIM INTEGRACIJAMA}

Korupcija nije pojava novijeg vremena. Potiče od latinske reči „,corruptus“, što znači pokvarenost, ucena, izopačenost, podmitljivost $i$ sl. Stari grci $i$ rimljani susretali su se sa ovom pojavom i donosili pravila u vezi njenog sprečavanja, odnosno suzbijanja. Praksa podmićivalja, stara je koliko i sama država. Na primer, u Engleskoj je pojam korupcije u 18. veku, pored činjenice o kvarenju vlasti, poistovećen i sa davanjem mita i podmićivanjem. Uprkos mnogobrojnim naporima međunarodne zajednice da stane na put ovom problemu, još uvek je prisutna činjenica, da veliki broj zemalja nije ratifikovao ponuđena dokumenta ove vrste. U krivično-pravnom smislu koruptivni delikti u Srbiji danas obuhvataju prvenstveno krivična dela protiv službene dužnosti, krivična dela protiv privrede i krivična dela protiv slobode i prava građana. U ovom radu autori su se dotakli pojedinih pitanja o korupciji kroz prizmu njenog negativnog uticaja na evropske integracije.

Ključne reči: korupcija, koruptivna krivična dela, sprečavanje i suzbijanje, zloupotreba, ekonomski razvoj.

Proofreading and copy-editing:

Gordana Ignjatović 